\title{
Moldovan Media Talk in the Aftermath of the 2015 Riga Eastern Partnership Summit
}

\author{
Onoriu Colăcel \\ Faculty of Letters and Communication Sciences, \\ University Ştefan cel Mare of Suceava, \\ Universităţii 13 , \\ Suceava 720229, Romania \\ E-mail: onoriucolacel@litere.usv.ro
}

Abstract: The delegation of the European Union to Moldova takes upon itself the task of making the case for the Association Agenda between the country and the EU. The European foreign policy in the borderlands of the Union is carried out against the background of the war in Eastern Ukraine. A war of words is being fought in Moldovan media as well. Mostly on Romanian-speaking TV, Pirkka Tapiola, the EU ambassador, is among those who lead the way. At a time of renewed Western concern about Eastern Europe, the media presence of the $E U$ in Moldova reveals anxieties about the future: once again, the former Soviet republic seems to be teetering on the brink of Russian control. The breakaway region of Trans-Dniester and the prospect of default are the two main concerns that the EU mission has to address while speaking the language of European politics in a country battered by corruption, high inflation, and unemployment. The discourse of Pirkka Tapiola, Head of the EU delegation, is an exercise in spokesmanship, which seems to underplay the seriousness of the situation. According to opinion polls conducted recently, the avowedly pro-Russian parties would win the next election. In hindsight, it is possible to surmise that the pro-EU parties pulled off a political coup by deferring the costs incurred during the mandates of the previous government coalitions. Parties whose constituencies are declining stayed in power, while better alternatives have developed: the new names that can be found on the right wing of the Moldovan political spectrum show that their electorate is ready to embrace the goal of European accession once again.

Keywords: EU delegation to Moldova, EU-Moldova, Moldovan media 


\section{Campaigning for Europe in the Republic of Moldova}

The attempt to foster closer ties between the European Union (EU) and the Republic of Moldova (RM) ranks high on the agenda of the Romanian-speaking media of the former Soviet republic. Probing into the immediate past of this 3 million people country demands a close look at the "soft power" (Nye, 2004, p. x) resources of the EU and of the Russian Federation. The analysis of media talk on prospective European accession points to a sharp conflict that mostly runs across ethnic and linguistic lines. Local media reports show that 2015 was the year the republic felt the brunt of social hardship and anger. The number of online and TV pieces covering the standoff sparked by the current economic woes facing Moldova peaked last year. Russian- and Romanianspeaking media outlets convey alarming messages about the future: a sense of impending disaster is felt nationwide. Tailored to particular audience segments, the messages of the delegation of the European Union to Moldova (DEUM) and of the Eurasian Customs Union (ECU) provide a glimmer of hope to each side, but never to a majority of Moldovan citizens. By looking at how pro-European media talk shapes the attitude of the public towards 'Europe', I try to delineate the highlights of the EU policy in Moldova. I contend that the new names that can be found on the right wing of the Moldovan political spectrum benefited from the expanding media presence of the EU, which helped break the former Russian monopoly over the local media industry.

Judging from the coverage the European Union gets in Moldovan mainstream media, the picture of the republic's association to the EU is quite clear. RM is a country battered by corruption, high inflation, and unemployment. On the one hand, support for EU seems to be waning (Quinlan, 2015) as the Party of Socialists of the Republic of Moldova (PSRM) won the parliamentary elections of November 2014. To add to the picture, 1 billion US dollars was stolen from Moldovan banks, utility rates went up, and the Head of DEUM, Pirkka Tapiola, announced on the 8th of July 2015 that "budget support for RM" was frozen "pending the fulfilment of several conditions" (EC, 2015). On the other hand, the Eastern Partnership Summit, held in Riga on 21-22 May 2015, showed that the prospect of the EU accession looks far less credible now than in the past. Currently, the Moldovan success story (EEAS, 2014) seems to be history.

From January 2010, when negotiations on an EU-Moldova Association Agreement (EC, 2014) started, democracy, rule of law and human rights are the buzzwords of Moldovan politics. Traditionally, the pro-European parties argued on behalf of the attempt to follow in the footsteps of Romania. The Association 
Agenda is on the table and it seems to be the focus of the campaign for Europe. To cut a long story short, the agenda tells to Moldovan citizens the story of the EU-Moldova Association Agreement in more user-friendly terms. Commonly, the Deep and Comprehensive Free Trade Area (DCFTA) and the Association Agreement (that replaced the Partnership and Cooperation Agreement) are under scrutiny. Except for the Russian-speaking community (generally committed to the Custom Union of Russia, Belarus, and Kazakhstan), the attitude of the Romanian-speaking Moldovans towards Europe was one of eagerness to play their part. Only a couple of years ago, media support for the EU accession seemed quite strong: for example, throughout 2014, privately owned national TV stations "showed a marked bias in favour of" the EU (Freedom House, 2015). Canal 2, Canal 3, Prime TV, Publika, Euro TV, N4, and TV 7, all side with parties whose main stated aim is EU integration. Even the public broadcaster Moldova 1 was "more positive toward the pro-EU governing parties" (Freedom House, 2015). Jurnal Trust Media (JTM) is among the staunchest defenders of European association. Particularly JurnalTV, a nationwide commercial TV broadcaster, makes a grand statement on the meaning of European citizenship. Informing the indigenous public of the EU ethics and defending the Westernization of Moldova are topical issues for JurnalTV. However, the values and the message of media talk are not confined to the TV set. "Performative features in media talk" (Tolson, 2006, p. 24) are copied out in web reporting. News providers quote full statements, words, or pictures on air the day before. Most of the times, some indication that news portals display the words of specific policymakers, media pundits, or journalists is given. The customary comment section of news websites is of help in bridging the distance between the public and events. Knowledge of events comes together as a narrative that conflates web reporting and traditional TV.

In 2015, the pro-EU parties pulled off a political coup by deferring the costs incurred during the mandates of previous government coalitions. DEUM seems to acknowledge the media environment that helped parties whose constituencies are declining to stay in power, while better alternatives have developed: the spectacular performance of the party that sprang from the Civic Platform for Dignity and Truth ${ }^{1}$ is compelling evidence that the right wing electorate was groomed to expect an alternative to the traditional pro-EU officials. ${ }^{2}$

\footnotetext{
1 Next to the pro-Russian Our Party, the DA Party topped the polls conducted in December 2015 with 18\% (politik.md, 2015).

2 Irrespectively, the avowedly pro-Russian parties would win the next elections, according to opinion polls conducted recently (Timpul.md, 2015).
} 


\section{The fresh start in pro-EU Moldovan politics}

The media of the post-Soviet state has undergone dramatic change in recent years. From communist print press and TV broadcasting to a "media landscape [which] is as divided as the country as a whole" (Lublinski et al., 2014, p. 11), both the Russian and the Romanian-language press share at least one concern. One time or another, they all have run titles such as "the power-broker who owns Moldova" ('Mai pe scurt'3; JurnalTV, 2015c) to bring attention to Vladimir Plahotniuc". The Moldovan oligarch makes the case for a providential hero, supposed to fight corruption and the Soviet past. The need for heroes rather than for policymakers has always been around, ever since the fall of the Soviet Union. Needless to say that for each of the concerned parties, rescue comes from two mutually exclusive realms: from Europe's promise of security and from the foreign policy of Russia. Their soft power in RM comes across as a challenging mix of literal threats and economic opportunities. Nevertheless, the two of them give structure to the Moldovan media talk, being the answers of the political leadership to the challenges posed by corruption and all-out war. In media battles, the EU supporters have put on the table a major new theme for their electorate: a long series of bodged attempts to appoint the country's premier. On 12 February 2015, Iurie Leanca ${ }^{5}$ failed to get the votes in the parliament and Maia Sandu did not even make it in the assembly. Moreover, the scenario was replicated in early January 2016. To be exact, after rejecting the bid of the same Vladimir Plahotniuc to become the head of government, Nicolae Timofti, the Moldovan President embarked on a similar attempt at appointing yet another premier who never stood a chance to win support in the parliament, Ion Sturza. A former Prime Minister

3 "To put it shortly" (the author's translation) is a five-minute broadcast on topical Moldovan issues hosted by Constantin Cheianu. The famous actor, journalist, and writer whose "Keep it brief" is on air from Monday to Thursday on the pro-European station JurnalTV is a staunch believer in the EU.

4 He is a Member of Parliament, the informal leader of the Democratic Party of Moldova (PDM), and a major player on the Moldovan media market. Media-related business in Moldova has to do with the Dutch off-shore OTIV Prime Holding B.V., believed to be linked to Vladimir Plahotniuc. Its subsidiary, OTIV Prime Media B.V. owns several advertising agencies, Angel-S SRL Casa Media Plus SRL, Casa Media SRL; the off-shore also founded Media Production SRL, Telefe M International SRL, and Prime TV SRL. The abovementioned companies operate the four TV stations (Publika TV, Prime TV, Canal 3 and Canal 2) and the three radio stations (MuzFM, MaestroFM, MegapolisFM) of the General Media Group. The online news portal 24h.md is associated to the same media holding (Moldovacurata.md, 2015).

5 A former Foreign Minister and PM of Moldova, who succeeded in bringing the country closer than ever to the EU; as a result of 12 February 2015, he resigned from PLDM; currently, he is chair of the newly founded Popular European Party. 
of Moldova for a few months in 1999, the millionaire businessman made a point out of being a staunch supporter of European accession. On 4 January 2016, Ion Sturza faced a half-empty assembly hall. The bodged 2015 campaign to appoint a pro-European Prime Minister showed that the political deadlock is centred on the dispute over the European or the Russian future of Moldova. Knowing full well that getting a majority in the Moldovan Assembly is not possible, the Liberal Democratic Party of Moldova (PLDM) ${ }^{6}$ various NGOs and the pro-European media pushed on against all odds. For example, Maia Sandu's name, an ex-World Bank economist and former education minister, popped up as a possible candidate for Prime Minister in the summer of 2015. The very moment PLDM circulated the news to the press, widespread disbelief was rampant ('Ora expertizei'7 ; JurnalTV, 2015b). However, her public standing was high enough to get her into the debate and her defeat prompted speculation that everything was a ploy to further boost her public image.

Irrespective of media talk on the European membership, support for the EU is dwindling (Cichowlas, 2015). Self-professed pro-European politicians have led the country on the brink of default. Since 2009, Moldova has pro-European parties at the helm of government. At the time, "the polls were won by the Communist Party with $44.7 \%$ of the vote [...] Opposition parties agreed to create the Alliance for European Integration that pushed the Communist Party into opposition. The Communists were in government since 2001." (IBP, Inc., 2014, p. 32) Ever since, the Moldovan Communists (PCRM) have lost ground in favour of other pro-Russian parties. ${ }^{8}$ Three parties, the Democratic Party of Moldova (PDM), the Liberal Democratic Party of Moldova, and the Liberal Party (PL) have been in three so-called alliances for European integration (AIE). Consequently, the pro-EU political elite is held accountable for the 1 billion US dollars that has gone missing from Moldovan banks.

Appropriately, the media presence of DEUM addresses specific issues. First of all, monitoring banking institutions seems to be the main concern. The delegation takes upon itself the task of making the case for heightened supervision of

6 Between 2012 and 2015, Maia Sandu was the Minister of Education of Moldova (in the Filat, Leanca and Gaburici governments) with the backing of PLDM; Ion Sturza is also believed to have been proposed by the same party.

7 "Expertise Time" (the author's translation) is one of the main talk show programmes aired on JurnalTV. On 23 July 2015, both the host Dumitru Mişin and his guests, three leaders of minor political parties Sergiu Mocanu, Mihai Godea, and Valeriu Saharneanu concluded that Maia Sandu was unlikely to succeed in her bid as she would face the opposition of PDM and PL, which turned out to be true.

8 Currently, PSRM and Our Party are the main advocates of the Eurasian Customs Union. 
Moldovan banks. Only then, the new government can pursue "economic reform [...] seen as essential to making the case for Europe" (Liddle, 2014, p. xxix). Fraud and embezzlement are issues that have to do with the daily life of the people. With the help of the EU ambassador to Moldova, the concerns of the average Moldovan citizen make it into the public debate. Secondly, foreign trade and the Ukrainian crisis are more often than not in the background of Moldovan media talk. The Deep and Comprehensive Free Trade Area (DCFTA) is supposed to counter the Kremlin's ban on Moldovan agricultural exports. For the people of Moldova, European foreign policy in the borderlands of the Union is carried out against the background of the war in Eastern Ukraine. Specifically, the threat of the Russian army stationed in the self-proclaimed Pridnestrovian Moldavian Republic looms over the daily life of Moldovans. In brief, the current circumstances of RM are rooted in the suspicion that it "is focused on following Romania's path into the European Union, [and] Russia sought to prevent Pridnestrovian Slavs, both Russian and Ukrainian, from being usurped by the Westernization of Moldova" (Hightower II, 2014, p. 57).

The indigenous media culture comes to show that the divide between Russianand Romanian-speaking citizens does not essentially go beyond ethnic boundaries. The legacy of the medieval Moldavian principality and the influx of "Slavic people" (Solonar \& Bruter, 1994) in its Eastern half," ever since it was incorporated into the Russian Empire (i.e., in 1812), should explain the current ethnic makeup of the country. ${ }^{10}$ They have led to the standoff between the EU and the Russian Federation in RM, something that also fuels the war of words on TV. The moment media content produced by Moldovans themselves takes over from prevalent Russian- or Romanian-made news or entertainment, conflicting narratives about the past of the country are in the spotlight. Service providers that rebroadcast mostly Russian TV expose the indigenous viewership to the propaganda machine of the Kremlin, ${ }^{11}$ while Romanian-speaking media sides with the EU. One way or another, foreign-made TV content is played at the expense of local TV industry that struggles to deliver home-grown news and entertainment.

9 The present-day Republic of Moldova, also known as Bessarabia.

10 According to the 2014 census (http://www.statistica.md/map.php?l=ro\&idc=205), the ethnic makeup is $56.8 \%(1,655,326)$ Moldovan, $23.2 \%(675,299)$ Romanian, $7.6 \%$ Ukrainian $(221,992)$ and 5.46\% Russian $(159,065)$.

11 General Media Group "re-broadcasts Russian TV on Channel One" (Socor, 2015) and Russian entertainment is what keeps the bilingual Moldovan viewers in front of the TV set. As a result, they are encouraged to watch Russian-language television (news programmes, American films dubbed in Russian, etc.). On the contrary, the policy of JTM is to have Moldovans speak for themselves, while Romanian news or entertainment is not aired on JurnalTV. 
Considering the discourse of policy-makers, clamping down on corruption is something both Russian and Romanian-speaking media asks for. So far, the attempt to come up with a credible response to popular demand for political accountability has delivered nothing but frustration. Looking from the outside, this is an opportunity to bridge the ethnic gap between the people of Moldova. As a result, the public found that some of the new names at the centre stage of politics might deliver on their promises. ${ }^{12}$ Although Maia Sandu "has a reputation of being a radical reformist" (Gillet, 2015), her public approval ratings seem to have reached all-time highs at the time ${ }^{13}$ when everybody asked for the appointment of a European chief public prosecutor in Moldova. Romanian- and English-speaking media covered small protests in favour of Maia Sandu: "Either give us Maia Sandu as Prime Minister or go away!" (EurAsia Daily, 2015). In early September 2015, social unrest reached a peak and tens of thousands took to the streets (Brett, Knott \& Popşoi, 2015) to demand the very same things JurnalTV had asked for throughout 2014. Mentioned all of a sudden and harshly brushed aside by the leaders of PDM, PLDM, and PL, Maia Sandu's public profile was bolstered by what Romanian-speaking media argued was an unfair rejection ('Ora de Ras' ${ }^{14}$; JurnalTV, 2015d). Irrespectively, everything happened all over again: in January 2016, Ion Struza filled the shoes of Maia Sandu. Although doomed to failure, these moves seem to have kept the country on the European path. Denying Maia Sandu and Ion Sturza the job might have served to enhance the waning appeal of European integration in Moldova.

Between freezing financial assistance programs (on 8 July 2015) and congratulating the newly appointed Prime Minister Valeriu Streleț (on 31 July 2015), Brussels helped bring together once more the three pro-European parties (PDM, PLDM, and PL) of the Alliance for European Integration. Paradoxically, the masterstroke of 2015 is that the failure to appoint the pro-European PM might turn out to be a boost to the country's movement away from the Soviet past.

12 Party leaders who openly acknowledged their pro-ECU stance (Igor Dodon or Renato Usatii) cashed in on the same frustration of the public with allegedly corrupt pro-EU officials.

13 On social media (Facebook, 27 July 2015), Maia Sandu posted her thanks to all those who have put their trust in her. She also explicitly mentioned the need for a common vision on democracy, shared by various government bodies, so that the head of government could work for the greater good of Moldovan society. On 28 July 2015, her statement was, for instance, quoted in Jurnal.md, the news portal of JTM (Jurnal.md, 2015a).

14 "The Hour of Reckoning" (the author's translation) is the flagship Sunday evening show of JurnalTV. The brand of "infotainment" pioneered by the two hosts, Anatol Durbală and Constantin Cheianu in the Romanian-speaking media of Moldova, is socially engaged and sets the policy of the TV station. 


\section{The EU Ambassador's message to Moldovans}

Spoken discourse on TV is broadly used by digital media outlets, which seem to report almost exclusively on yesterday's statements made on camera by talk show guests. In present-day Moldova, there are a number of rhetorical commonplaces recorded in the language of TV and web news. Elected officials, political pundits, or journalists are trying to relate current events with the politics of one political bloc or another. It is worth mentioning some of the most conspicuous: the war close to Moldovan Eastern borders, breakaway regions that either have claimed independence from Chişinău or threaten to do so, looming bankruptcy. In the summer of 2015, they all painted a bleak picture of the future. The appointment of the Streleţ government on the 27th of July 2015, the promise of an IMF financial package and resumed European budget support appeared to save the country from financial meltdown. However, nothing actually happened in the short-lived government headed by Valeriu Streleţ who stayed in office for only three months. All the more reason why the debate over the future of the country rages in media. Whenever Russian or European diplomats address a few words to Moldovans, their performance is over-scrutinized in search of clues, messages, etc. It goes without saying that DEUM is clearly on-message with Brussels' "Eastern Partnership" programme. Although the Riga summit reaffirmed the commitment of EU to Eastern partners, nonetheless, among pro-European commentators in Moldova there is a distinct sense of failure (TV7, 2015).

On 17 July 2015, the ambassador Pirkka Tapiola was the guest of the TV talk show 'Ora expertizei' aired on JurnalTV (2015a). Unambiguously, he underplayed the seriousness of the situation in Moldova. Again and again, the audience was told that the political leadership can always turn around a small country on the brink of ruin. The EU tries to get across a positive message: current developments in RM need to be judged mostly by practical standards. The moral expectations of the Moldovan public are recognised, yet the ambassador urges dialogue between the people and their elected representatives, no matter how disappointed citizens and European officials have become with the AIE and what happened after the Streleţ government was deposed. The host, Dumitru Mişin, looked for answers on the consequences of the November 2014 elections, when proEuropean parties secured victory by a narrow margin once more. He started by informing the audience that JurnalTV decided to resume the media campaign of 2014 'Europa, te aştept' (JurnalTV, 2014). ${ }^{15}$ Dumitru Mişin pointed out that

15 "Europe, I am waiting for you" (the author's translation). Throughout the year of parliamentary elections, JTM promoted success stories that have to do with EU investment and campaigned for the European accession of Moldova. 
despite such campaigns, support for the EU is falling due to the rocky start of 2015. Both the Moldovan host and the Finnish diplomat tried to dispel the myth that the EU might sanction aid to Moldova exclusively in response to Russia's obvious interest in RM. In addition, the ambassador had to dismiss rumours that Brussels is not looking seriously at the AIE's record over the years. The assumption of unconditional European support to PLDM, PDM, or PL was proven wrong. The issue had to be addressed considering that "the meganetwork SPUTNIK Moldova of Kremlin (EURO TV, Alt TV, UniversFM, Ria Novosti, etc.)" (Jurnal.md, 2015c) dutifully reported on the waning appeal of the EU among Moldovans. According to the "Moldovan pollster CBS-AXA" ( $S N$, 26 May 2015), there is a tendency to equate EU with AIE. In the words of Pirkka Tapiola, the media presence of DEUM is meant to prove the opposite: the EU does not condone the questionable decision-making that has led to the current circumstances. Consequently, the way Moldovan politicians mismanaged the opportunity of the last election is under scrutiny. Repeatedly, the host attempts to set apart pro-European citizens from the political establishment who took charge of the country following the ousting from power of PCRM back in 2009. Mişin calls names and points fingers while the EU ambassador is ready only to acknowledge disappointment. He is keen to emphasize, however, that the need to work with the elected officials of the country has become critical. Although Pirkka Tapiola does not go along with the outspoken comments of the JurnalTV journalist, his presence helps prove that both 'Ora Expertizei' and JurnalTV are prominent examples of Moldovan civic involvement. Conspicuously, the TV station and the Civic Platform for Dignity and Truth ${ }^{16}$ (DA) - a nongovernmental organization that successfully organized massive street protests throughout 2015 - stand in contrast to the parties of AIE. Even though they all seem advocate the European values of good governance, political accountability, etc. there is a huge rift between them.

16 JTM does not only cover mass street protest against PLDM, PDM and PL at great length, it seems that prominent members of the non-governmental organization Demnitate Şi Adevăr (Dignity and Truth, also known as The Civic Platform for Dignity and Truth), which takes responsibility for the protest marches and sit-ins of 2015, are given moral support by the TV station. What is more, leading JurnalTV entertainers and journalists (Anatol Durbală, Constantin Cheianu, etc.) openly call for bringing to justice the leaders of PLDM and PDM. On TV, they demand the resignation of magistrates, and plead with their audience to express sympathy with the political cause of DA by attending future street protests. It feels safe to say that JurnalTV's news programmes, talk shows, and infotainment unabashedly promote civil unrest. Surprisingly or not, a number of TV station employees joined the people who want to have in jail Vladimir Plahotniuc for the theft of the 1 billion US dollars. 
I find that Pirkka Tapiola acknowledges Maia Sandu, DA, JTM and their struggle to lay bare corruption in a number of public bodies. This is a highly contentious matter, tentatively addressed by DEUM, although corruption itself never goes unmentioned. Take for example, Maia Sandu's forthright comments on the judiciary, which "hinders the reform of education" (IPN, 2014). Fraud, bribery, and embezzlement are openly mentioned in relation with particular members of the government or informal leaders of the AIE. What brings together the various strands of opposition to the alliance is the appropriation of the customary discourse European officials use when it comes to lack of integrity in the discharge of public duties. As a result, the leaders of the AIE parties must feel that they ${ }^{17}$ are personally threatened by the charges brought to them by DA and JTM. 'Ora Expertizei' plays its part in the effort to expose them. The talk show is known for delivering one of the most critical reports of public spending, dodgy government practices, and of the involvement political decision-makers must have had in the "great Moldovan bank robbery" (Whewell, 2015). Although the Head of DEUM does not take sides, his presence on JurnalTV is a means to bolster the public perception that there is opposition to AIE 3 (the 2015 agreement between PLDM, PDM and PL is the third one they have signed so far). Ultimately, the talk show proves that there is a part of Moldovan society that, in due time, will replace the current political leadership whose record on corruption is decidedly questionable. The ambassador makes clear that Europe was forced into a situation where it had to associate with the AIE.

\section{Conclusions}

The post-Soviet culture of Moldovan media talk features two separate but overlapping trends best described as the pro-EU stance versus the Pridnestrovian option for the ECU. The main pitfalls and opportunities Moldovan viewers need to consider when exposed to TV talk and web reporting on RM are steeped in the tradition of the East-West clash. As a result, the Moldovan media talk fails to represent the Moldovan society as a multicultural one. The prospect of accession to either the EU or the ECU only serves to reinforce the message of impending doom now in the mainstream of Moldovan life.

17 Alongside Vladimir Plahotniuc, Marian Lupu (the chairman of PDM), Vlad Filat (the leader of PLDM, now in jail) or Mihai Ghimpu (the chair of PL) are called names like "oligarch" (Jurnal.md, 2015b). Likewise, popular protest targets Vladimir Plahotniuc and Vladimir Filat, while the highest ranks of political elite (for instance, the former Prime Minister Chiril Gaburici) are deemed accessories to economic crimes perpetrated against Moldovan citizens. 
As a result, the post-Riga public discourse is riddled with anecdotal evidence of who is to blame for the current state of affairs. The media champions of the EU, Maia Sandu, Ion Sturza or Andrei Năstase ${ }^{18}$, are no exception. Pirkka Tapiola voices judgments concerning the commitment of RM to reform, while the establishment in charge of implementing change goes unmentioned. Maia Sandu points the finger at dubious political dealings. Against the polls, Andrei Năstase calls for early elections; Ion Sturza's feisty defence of Moldova's European commitments rounds up the picture.

The pitfalls and opportunities of binary thinking are plain to see in the Moldovan media landscape. On the one side, there are Sputnik Moldova and various other Russian TV stations readily available to all Moldovans. ${ }^{19}$ For example, on 8 December 2015, the Media Coordinating Council of Moldova granted the broadcasting licence to a new commercial TV station, NTV Moldova (Terra. $m d, 2015)$. In fact, the regulating body allowed the news programmes of NTV, the commercial TV station owned by Gazprom-Media, ${ }^{20}$ to make their way in the mainstream media. In stark contrast, the pro-European media is mostly confined to Romanian-speaking TV and radio, alongside print and online newspapers. The Romanian language seems to be the most important vehicle of the EU in Moldova. As a matter of principle, it seems that mostly journalists working in Romanian-speaking media consistently advocate a pro-European stance. The EU's media presence in Moldova is associated with news providers whose language of choice seems to be Romanian, although Russian and, lately, English are common in Moldovan news reporting. However, most online outlets deliver content in a multilingual environment, irrespective of their political commitments.

The Russian-speaking media is less concerned with the power struggle amongst the supporters of ECU. Instead, they persuade by example and focus on the proEuropean camp. The soft power of the Kremlin owes much of its success to the consistent message of Russian media talk. Meanwhile, although the number and the influence of Romanian-speaking media increased steadily, the pro-European side is bitterly divided over the political elite of the country. Somewhat alone, Jurnal Media Trust (JMT) backs up Maia Sandu, Andrei Năstase or Ion Sturza. Although Maia Sandu just announced her own party (Zdg.md, 2015), the new DA party is said to bring together some, if not most of the EU's media

18 The leader of the newly set-up Dignity and Truth Party (DA Party).

19 Moldovan media has a long tradition of re-broadcasting Russian news, entertainment, etc.; most, if not all, Russian-speaking media outlets (commercial TV, radio, print press) carry Russian-made content.

20 TV7, a commercial TV station used to re-broadcast NTV programmes in the past. 
champions in RM. Openly at odds with the message of Russian-speaking media talk (as well as with Vladimir Plahotniuc's General Media Group that covers both the Romanian- and Russian-speaking markets), the target of Jurnal Media Group is the owner of General Media Group and his self-declared pro-European Democratic Party of Moldova. The vibrant media scene of Moldova benefitted hugely from the presence of Romanian-speaking TV stations; likewise, the support they received from DEUM meant that the Russian soft power finally faced a worthy opponent in RM. One way or another, the former Russian monopoly over the local media industry is not what it used to be anymore. News content on the web adds to the message of traditional TV and print media, building audience awareness among a young and relatively well-off Moldovan public. The expanding media presence of the EU is part of the reason why the current language of Moldovan media talk is not exclusively Russian, but also Romanian and, sometimes, English. ${ }^{21}$

Dr. Onoriu Colăcel is lecturer of British Studies and English Literature at the Faculty of Letters and Communication Sciences of Stefan cel Mare University, Romania. His work focuses on contemporary English literature and patterns of self-identification in literature and popular culture.

\section{References}

Brett, D.; Knott, E. \& Popşoi, M. (2015), “The 'billion dollar protests' in Moldova are threatening the survival of the country's political elite," EUROPP blog, 21 September. Retrieved from http://blogs.lse.ac.uk/europpblog/2015/09/21/thebillion-dollar-protests-in-moldova-are-threatening-the-survival-of-the-countryspolitical-elite/\#Author [accessed 21 Sep 2015]

Cichowlas, O. (2015), 'Moldova is hanging by a thread,' Politico, 5 May. Retrieved from http://www.politico.eu/article/moldova-is-hanging-by-a-thread/ [accessed 7 Aug 2015]

EC (2014), The EU-Moldova Association Agreement, Official Journal of the European Union, L 260, vol. 57, 30.8.2014. Retrieved from http://eeas.europa.eu/moldova/ [accessed 31 Mar 2015]

— (2015), Delegation of the EU to Moldova: EU Budget Support for the Republic of Moldova - pending the fulfilment of several conditions, 8.07.2015. Retrieved form http://eeas.europa.eu/delegations/moldova/index_en.htm [accessed 6 Aug 2015]

21 More often than not, English is also widely used by Moldovan online news outlets. 
EEAS (2014), EU Relations with Eastern Partnership, retrieved from http://eeas.europa. eu/eastern/about/index_en.htm, [accessed 06.08.2015].

EurAsia Daily (2015), 'New Cabinet to be elected in Moldova. People are protesting,' 29 July. Retrieved from http://en.eadaily.com/news/2015/07/29/-new-cabinet-tobe-elected-in-Moldova-people-are-protesting, [accessed 9 Aug 2015]

IBP, Inc. (2014), Moldova: Constitution and Citizenship Laws Handbook, Vol. 1: Strategic Information and Developments, Washington: International Business Publications.

IPN (2014), "Maia Sandu: Judiciary hinders reform of education”, 24 December. Retrieved from http://www.ipn.md/en/societate/66662 [accessed 10 Aug 2015]

Freedom House (2015), Moldova: Freedom of the Press 2015. Retrieved from https:// freedomhouse.org/report/freedom-press/2015/moldova\# [accessed 5 Aug 2015]

Gillet, K. (2015), 'With new PM in place, Moldova looks to recover from rocky start to 2015?' bne IntelliNews, 7 August. Tetrieved from http://www.bne.eu/content/ story/new-pm-place-moldova-looks-recover-rocky-start-2015 [accessed 8 Aug 2015]

Hightower II, R., L. (2014), 'The Declarations of Independence. The Pridnestrovian Moldavian Republic,' in V. Franke, K. Guttieri \& M.A. Civic (eds.) Understanding Complex Military Operations: A Case Study Approach, Abingdon \& New York: Routledge, pp. 46-67.

JurnalTV (2014), 'Europa, te aştept', 19 June. Retrieved from http://www.jurnaltv.md/ ro/news/2014/6/19/Europa-te-astept-promo [accessed 13 Apr 2015]

(2015a), 'Ora expertizei,' 17 June. Retrieved from http://www.jurnaltv.md/ro/ news/2015/7/23/o-noua-veche-alian-a-de-guvernare-10143443/\#1; http://www. jurnaltv.md/ro/news/2015/7/17/europa-te-a-tept-10141921/\#2 [accessed 20 Aug 2015]

— (2015b), 'Ora expertizei,' 23 June. Retrieved from http://www.jurnaltv.md/ro/ news/2015/7/17/europa-te-a-tept-10141921/\#2 [accessed 1 Aug 2015]

(2015c), 'Mai pe scurt,' 27 July. Retrieved from http://www.jurnaltv.md/ro/ news/2015/7/27/clanul-papu-arului-vs-protestul-popular-10144563/\#1 [accessed 29 Jul 2015]

— (2015d), 'Ora de ras' (2015), JurnalTV, 2 August. Retrieved from www.jurnaltv. $\mathrm{md} / \mathrm{ro} / \mathrm{news} / 2015 / 8 / 2 /$ ora-de-ras-2-august-10145935 [accessed 8 Aug 2015]

Jurnal.md (2015a), 'Maia Sandu: PL and PD categorically refused to discuss with me,' 28 July. Retrieved from http://www.jurnal.md/en/politic/2015/7/28/maia-sandupl-and-pd-categorically-refused-to-discuss-with-me/ [accessed 6 Aug 2015]

— (2015b), 'Sturza: A collective Plahotniuc is the only powerhouse in the RM,' 27 January. Retrieved from http://jurnal.md/en/politic/2015/1/27/sturza-acollective-plahotniuc-is-the-only-powerhouse-in-the-rm/ [accessed 10 Aug 2015] (2015c), 'The billion of the Russian propaganda,' 14 August. Retrieved from 
http://www.jurnal.md/en/politic/2015/8/14/the-billion-of-the-russian-propaganda/ [accessed 17 Aug 2015]

Liddle, R. (2014), The Europe Dilemma. Britain and the Drama of EU Integration, London and New York: I B Tauris.

Lublinski, J.; Albrecht, E.; Berner, P.; Schneider, L.; Wakili, M. \& Wilson, J. (2014), 'From the field: windows of opportunity - the transformation of state media to public service media in Kyrgyzstan, Mongolia, Moldova and Serbia,' Global Media Journal: German Edition, vol. 4, no. 2 (Autumn/Winter), pp. 1-30. URN:nbn:de:gbv:547-201400801

Moldovacurata.md (2015), 'Ziarul Naţional: imperiul lui Plahotniuc.' Retrieved from http://www.moldovacurata.md/interese-avere-la-vedere/avere-la-vedere/ziarulnational-imperiul-lui-plahotniuc [accessed 25 Dec 2015]

Nye, J. S. (2004), 'Preface,' in J. S. Nye (ed.) Soft Power: The Means to Success in World Politics, New York: Public Affairs, pp. ix-xiv.

politik.md (2015), 'BOP: Şapte partide ar accede în Parlamentul viitor.' Retrieved from http://politik.md/articles/sondaje/bop-sapte-partide-ar-accede-in-parlamentulviitor/35256/ [accessed 25 Dec 2015]

Quinlan, P. D. (2015), 'Moldova and the crisis in Ukraine,' Paper presented at The 2015 International Conference Linking Past, Present, and Future: The 25th Anniversary of Regime Change in Romania and Moldova (1989/1991), Bucharest, Romania, 17-19 June 2015.

Socor, V. (2015), “Moldova's New Government: Daunting Challenges Ahead," Eurasia Daily Monitor, vol. 12, no. 42, 6 March. Retrieved from http://www.jamestown. org/single/?tx_ttnews\%5Btt_news\%5D=43628\&no_cache=1\#.Vp-juI9OKP8 [accessed 30 Mar 2015]

Solonar, V. \& Bruter, V. (1994), 'Russians in Moldova,' in V. Shlapentokh, M. Sendich \& E. Payin (eds.) The New Russian Diaspora: Russian Minorities in the Former Soviet Republics, New York: M. E. Sharpe, pp. 72-90.

SPUTNIK News (2015), 'Pro-European Parties Lose Support in Moldova,' 26 May. Retrieved from http://sputniknews.com/politics/20150526/1022580686.html [accessed 10 Aug 2015]

Terra.md (2015), 'CCA a acordat licenţă de emisie postului ntv, care ar aparţine unui deputat PSRM.' Retrieved from http://www.terra.md/ro/news/moldova/cca-aacordat-licenta-de-emisie-postului-ntv-care-/default.aspx [accessed 20 Dec 2015] Timpul.md (2015), '(SONDAJ) Moldovenii au încredere în Partidul Nostru, Platforma DA, PSRM, PPEM. Maia Sandu și Leancă, aleși pentru funcția de premier.' Retrieved from http://www.timpul.md/articol/\%28sondaj\%29-moldovenii-auincredere-in-partidul-nostru-platforma-da-psrm-ppem--maia-sandu-i-leanca-aleipentru-funcia-de-premier-84193.html [accessed 25 Dec 2015] 
Tolson, A. (2006), Media Talk: Spoken Discourse on TV and Radio, Edinburgh: Edinburgh University Press.

TV7 (2015), 'Interpol,' 16 July. Retrieved from http://tv7.md/ro/interpol/16-07-2015interpol-cu-igor-bo-an [accessed 11 Aug 2015]

Whewell, T. (2015), 'The great Moldovan bank robbery,' BBC News, 18 June. Retrieved from http://www.bbc.com/news/magazine-33166383 [accessed 10 Aug 2015]

Zdg.md (2015), 'Exclusiv: Cum se va numi partidul condus de Maia Sandu.' Retrieved from http://www.zdg.md/stiri/exclusiv-cum-se-va-numi-partidul-condus-de-maiasandu [accessed 7 Jan 2016] 